CLINICAL STUDY

\title{
Simultaneous expression analysis of vitamin $D$ receptor, calcium-sensing receptor, cyclin D1, and PTH in symptomatic primary hyperparathyroidism in Asian Indians
}

\author{
Shweta Varshney*, Sanjay Kumar Bhadada*, Uma Nahar Saikia ${ }^{1}$, Naresh Sachdeva, Arunanshu Behera ${ }^{2}$, \\ Ashutosh Kumar Arya, Sadhna Sharma ${ }^{3}$, Anil Bhansali, Ambrish Mithal ${ }^{4}$ and Sudhaker D Rao ${ }^{5}$ \\ Department of Endocrinology, Postgraduate Institute of Medical Education and Research, 4th Floor, F-Block, Room No. 2, Chandigarh 160012, India, \\ Departments of ${ }^{1}$ Histopathology, ${ }^{2}$ General Surgery and ${ }^{3}$ Biochemistry, Postgraduate Institute of Medical Education and Research, Chandigarh 160012, \\ India, ${ }^{4}$ Medanta - The Medicity Hospital, Gurgaon, India and ${ }^{5}$ Bone and Mineral Research Laboratory, Henry Ford Hospital, Detroit, Michigan, USA \\ (Correspondence should be addressed to S K Bhadada; Email: bhadadask@rediffmail.com)
}

*(S Varshney and S K Bhadada contributed equally to this work)

\begin{abstract}
Background: To explore underlying molecular mechanisms in the pathogenesis of symptomatic sporadic primary hyperparathyroidism (PHPT).

Materials and methods: Forty-one parathyroid adenomas from patients with symptomatic PHPT and ten normal parathyroid glands either from patients with PHPT $(n=3)$ or from euthyroid patients without PHPT during thyroid surgery $(n=7)$ were analyzed for vitamin D receptor (VDR), calcium-sensing receptor (CASR), cyclin D1 (CD1), and parathyroid hormone (PTH) expressions. The protein expressions were assessed semiquantitatively by immunohistochemistry, based on percentage of positive cells and staining intensity, and confirmed by quantitative real-time PCR.

Results: Immunohistochemistry revealed significant reductions in VDR (both nuclear and cytoplasmic) and CASR expressions and significant increases in CD1 and PTH expressions in adenomatous compared with normal parathyroid tissue. Consistent with immunohistochemistry findings, both VDR and CASR mRNAs were reduced by 0.36 - and 0.45 -fold change $(P<0.001)$ and $C D 1$ and PTH mRNAs were increased by 9.4- and 17.4-fold change respectively $(P<0.001)$ in adenomatous parathyroid tissue. PTH mRNA correlated with plasma PTH $(r=0.864 ; P<0.001)$, but not with adenoma weight, while $C D 1$ mRNA correlated with adenoma weight $(r=0.715 ; P<0.001)$. There were no correlations between VDR and CASR mRNA levels and serum Ca, plasma intact PTH, or 25-hydroxyvitamin D levels. In addition, there was no relationship between the decreases in VDR and CASR mRNA expressions and the increases in PTH and CD1 mRNA expressions.

Conclusions: The expression of both VDR and CASR are reduced in symptomatic PHPT in Asian Indians. In addition, CD1 expression was greatly increased and correlated with adenoma weight, implying a potential role for CD1 in adenoma growth and differential clinical expression of PHPT.
\end{abstract}

European Journal of Endocrinology 169 109-116

\section{Introduction}

Primary hyperparathyroidism (PHPT) is a common sporadic endocrine disorder characterized by hypercalcemia with non-suppressed or elevated parathyroid hormone (PTH) levels. A single parathyroid adenoma is the most common cause of PHPT (1), but the pathogenesis of these lesions is poorly understood. Altered calcium-sensing receptor (CASR)-mediated control of PTH secretion with the consequent increased parathyroid cell proliferation is fundamental to the development of PHPT $(2,3)$. In addition, 1,25dihydroxyvitamin $\mathrm{D}$, through its interactions with vitamin D receptor (VDR) in parathyroid cells, modulates parathyroid function and growth $(4,5,6,7,8)$.
Thus, both VDR and CASR play critical roles in the regulation of PTH synthesis and secretion, parathyroid cell proliferation, and maintenance of plasma calcium levels. Tumor-specific DNA rearrangements in a subset of parathyroid adenomas have shown overexpression of cyclin D1 (CD1) leading to increasing mitotic rate and parathyroid adenoma development $(9,10,11)$.

Abnormalities in VDR $(12,13,14)$, CASR $(14,15$, $16,17,18)$, and CD1 $(19,20,21,22,23)$ expression have been reported in the cases probably having mild form of PHPT, parathyroid cancers, and renal secondary hyperparathyroidism. However, very little is known about such abnormalities in adenomas from patients with symptomatic sporadic PHPT $(24,25,26)$. Presentation of PHPT in Asian Indian is symptomatic 
unlike the mostly asymptomatic nature of presentation in the West (24). Accordingly, we examined the expression of VDR, CASR, CD1, and PTH using immunohistochemistry and confirmed with mRNA analyses in a cohort of parathyroid adenomas from Asian Indian patients with symptomatic PHPT.

\section{Materials and methods}

\section{Patient description and tissue collection}

The study was conducted at the Post Graduate Institute of Medical Education and Research (Chandigarh, India) from January 2008 to December 2010. After approval by the Institutional Ethics Committee, informed written consent was obtained from each patient. The diagnosis of PHPT was confirmed in each patient by the presence of hypercalcemia and elevated PTH levels and verified at surgery. Patients with parathyroid hyperplasia, secondary hyperparathyroidism, and multiple endocrine neoplasia syndromes were excluded.

Histopathologically confirmed parathyroid adenomas $(n=41)$ were collected immediately in RNA-Later and stored at $-80{ }^{\circ} \mathrm{C}$ until isolation of total RNA. Paraffin blocks of each tumor were retrieved from the Department of Histopathology. Normal parathyroid tissue $(n=10)$ was obtained either from PHPT patients $(n=3)$ or from patients undergoing thyroid surgery for euthyroid goiters in whom parathyroid gland was inadvertently removed.

\section{Assay methods}

Preoperative serum calcium, adjusted for serum albumin (reference range (RR), 8.6-10.2 mg/dl), alkaline phosphatase (RR, 40-129 U/l), and creatinine (RR, 0.5-1.2 mg/dl) were measured by auto-analyzer (Modular P 800: Roche Diagnostics). Plasma intact PTH (RR, 15-65 pg/ml) and 25-hydroxyvitamin D (RR, $11.1-42.9 \mathrm{ng} / \mathrm{ml}$ ) levels were measured by electrochemiluminescence immunoassay (ELECSYS-2010, Roche Diagnostics) as per the manufacturer's instructions.

\section{Histopathology}

After surgical excision, the specimens were weighed and fixed in 10\% buffered formalin and embedded in paraffin for routine processing and paraffin blocking. A 3-5 $\mu$ m-thick section was cut from each paraffinembedded block stained with hematoxylin and eosin (H\&E) and assessed by an expert parathyroid histopathologist (U N Saikia) to confirm the diagnosis of parathyroid adenoma as determined by an encapsulated tumor with very little fat associated with hypercellularity. Images were captured using a Leica DMR microscope (Leica, Germany) and a monochrome photometrics CCD camera (Photometrics, USA).

\section{Immunohistochemistry}

Representative paraffin blocks were retrieved and immunostained as previously reported $(12,22)$ and incubated with peroxidase-labeled secondary antibody (rabbit/mouse, Dako, Glostrup, Denmark). At a magnification of $20 \times$ and $40 \times, \sim 500$ cells were counted at four different locations for each section. Results were scored semiquantitatively based on percentage of positive cells and staining intensity. Detailed information on materials and methods for immunostaining are shown in Supplementary Table 1, see section on supplementary data given at the end of this article, and the scoring criteria for stain intensity of each antibody are in Supplementary Table 2.

\section{RNA extraction and cDNA synthesis}

Briefly, each tissue sample was crushed in $1 \mathrm{ml}$ TRI reagent (Sigma-Aldrich). After chloroform addition, the aqueous and organic phases were separated by centrifugation. The aqueous (upper) phase was removed from each tube and transferred to a clean $1.5 \mathrm{ml}$ microcentrifuge tube, where total RNA was precipitated by isopropanol. The RNA pellet was washed with $75 \%$ ethanol, allowed to dry, and dissolved in sterile water and stored at $-20{ }^{\circ} \mathrm{C}$ until analysis. The $260: 280 \mathrm{~nm}$ ratio of RNA (interval 1.9-2.1) was determined by Biophotometer plus (Eppendorf, Hamburg, Germany). The integrity was confirmed by denaturing gel electrophoresis, whereby sharp $28 \mathrm{~S}$ and $18 \mathrm{~S}$ bands were demonstrated. The cDNA was synthesized from $6 \mu \mathrm{g}$ of total RNA by cDNA synthesis Kit (Fermentas, Life Sciences, Vilinus, Lithuania), according to the manufacturer's protocol.

\section{Gene expression analysis}

The relative expression of VDR, CASR, CD1, and PTH in parathyroid adenoma cells was determined using quantitative real-time PCR (qRT-PCR) by SYBR Green I dye method (Fermentas, Life Sciences) on Light Cycler 480 Real-Time PCR System (Roche Diagnostics) as per the manufacturer's recommendations. All samples were amplified in duplicate; non-template reactions were included as a negative control. Throughout qRT-PCR analysis, product identities were confirmed by melting curve analysis (Supplementary Figure 1, see section on supplementary data given at the end of this article).

Primers were designed using a web-based application (www.ncbi.nlm.nih.gov/tools/primer-blast/; Supplementary Table 3). All reactions were carried out in a 96-well optical reaction plate. A $1 \mu \mathrm{l}$ volume of template cDNA (equivalent to $300 \mathrm{ng}$ of total RNA) was added to $25 \mu \mathrm{l}$ of PCR mixture containing $0.5 \mu \mathrm{M}$ each forward and reverse primers. The pre-incubation was done at $95^{\circ} \mathrm{C}$ for $10 \mathrm{~min}$, followed by 50 cycles of PCR amplification $\left(95^{\circ} \mathrm{C}, 15 \mathrm{~s}\right.$; variable annealing temperature; $72{ }^{\circ} \mathrm{C}, 20 \mathrm{~s}$ ), melting at $70^{\circ} \mathrm{C}$, for $1 \mathrm{~min}$ and final 
step was extended to $10 \mathrm{~min}$ at $72{ }^{\circ} \mathrm{C}$. To confirm specificity of the primers, gel electrophoresis of the PCR products revealed one distinct band for each transcript. Finally, sequencing of the amplified product was performed (Applied Biosystems) to confirm the correct transcript. Amplification efficiencies of the targets and reference were found to be approximately equal. So analysis of the relative gene expression data was done by the $2^{-\Delta \Delta C p}$ method to produce the data as fold change up- or downregulation (27). In the fold change analysis, crossing point $(\mathrm{Cp})$ value was determined as the number of cycles required for fluorescent signal to cross the threshold. The $\mathrm{Cp}$ values of both the calibrator (Control) and the sample of interest were normalized to the corresponding mean value of an endogenous housekeeping gene, GAPDH.

\section{Statistical analyses}

All analyses were performed using SPSS (10.01). The nonparametric Kolmogorov-Smirnov test was used to assess differences in all the study parameters between normal and adenomatous parathyroid samples. Values are presented as mean \pm s.D. Mann-Whitney, $\chi^{2}$, and $t$-tests were performed as appropriate to compare the data between normal and adenomatous tissue. The Spearman's $\rho$ correlation test was applied for correlation analyses. The percentage of positive cells and staining intensity were compared using the Wilcoxon's signed rank test. A $P$ value of $<0.05$ was considered statistically significant.

\section{Results}

\section{Clinical characteristics}

Of the 55 consecutive patients who underwent parathyroidectomy during the study period, 41 patients (74.5\%) had single adenomas, 12 (21.8\%) had hyperplasia, and $2(3.6 \%)$ had carcinoma. All the 41 parathyroid adenomas were included for detailed molecular studies. The mean age was $41.5 \pm 13.3$ years (range 11-67 years) with a male to female ratio of 1:3.2. The most common presenting manifestation was bone pain in $22(52 \%)$ followed by renal stones in $17(41 \%)$, fractures in $15(36 \%)$, nephrocalcinosis and gall stones in 7 (17\%) each, and pancreatitis in $5(12 \%)$ patients. The relevant baseline biochemical measurements are shown in Table 1.

\section{VDR expression}

Thirteen $(32 \%)$ of the parathyroid adenomas showed only cytoplasmic immunoreactivity for VDR while 26 (63\%) showed both nuclear and cytoplasmic positivity and only $2(5 \%)$ showed exclusive nuclear positivity. The mean proportion of adenomatous cells positive for VDR nuclear stain was 4\% (median: 2\%; range 0-40\%) compared with 75\% (median: 75; range 60-90\%) in normal parathyroid tissue cells $(P<0.05$, Fig. 1A). The mean proportion of adenomatous cells positive for cytoplasmic VDR stain was 29\% (median: 30; range $0-70 \%$ ) compared with 84\% (median: 85; range $70-100 \%)$ in normal parathyroid cells $(P<0.05$; Fig. 1A). Staining intensity was $1+$ in $17(42 \%), 2+$ in $22(54 \%)$, and $3+$ in $1(2 \%)$ adenomas and one adenoma $(2 \%)$ had neither nuclear nor cytoplasmic positivity. All normal parathyroid cells showed 3+ staining intensity (Fig. 2), with a relative reduction in VDR expression of about $71 \%$ in nuclear and $55 \%$ in cytoplasmic stain $(P<0.05)$ in all the adenoma cells.

In qRT-PCR analysis, VDR mRNA expression was also reduced in 93\% of adenoma cells with a fold change value of $0.36 \pm 0.29$ compared with normal parathyroid tissue cells $(P<0.001$; Fig. 3A). The frequency of VDR under-expression was not correlated with indices of disease (albumin-adjusted calcium, intact PTH, 25-hydroxyvitamin D, or adenoma weight).

\section{CASR expression}

All the parathyroid adenomas showed membranous positivity similar to normal parathyroid tissues, but the mean proportion of positive cells was $56.3 \pm 15.9 \%$ compared with $78 \pm 10.3 \%$ in normal parathyroid tissue cells $(P<0.05$, Fig. 1B). Staining intensity was $1+$ in $19(46 \%), 2+$ in $15(37 \%)$, and $3+$ in $7(17 \%)$

Table 1 Relevant biochemical measurements of the PHPT patients and controls. Data are expressed as mean (s.D.) and median.

\begin{tabular}{lcccr}
\hline Variables & Reference range & Adenoma $(n=41)$ & Control $^{\mathrm{a}}(n=10)$ & $\boldsymbol{P}$ value \\
\hline Corrected calcium $(\mathrm{mg} / \mathrm{dl})$ & $8.6-10.2$ & $12.1 \pm 1.8(11.7)$ & $9.2 \pm 0.4(9.2)$ & $<0.001$ \\
Alkaline phosphatase $(\mathrm{U} / \mathrm{l})$ & $40-129$ & $336.0 \pm 347.1(238)$ & $80.3 \pm 29.3(75.5)$ & $<0.001$ \\
Creatinine $(\mathrm{mg} / \mathrm{dl})$ & $0.5-1.2$ & $1.3 \pm 1(1)$ & $0.9 \pm 0.7^{\mathrm{b}}(0.7)$ & - \\
Intact PTH $(\mathrm{pg} / \mathrm{ml})$ & $15-65$ & $678.5 \pm 727.7(275)$ & $24.5 \pm 11.7(21.0)$ & $<0.001$ \\
25-Hydroxyvitamin D $(\mathrm{ng} / \mathrm{ml})$ & $11.1-42.9$ & $24.5 \pm 19.1(19.4)$ & $23.9 \pm 8.4(23.03)$ & 0.5 \\
Adenoma weight $(\mathrm{g})$ & & $4.5^{\mathrm{c}} \pm 3.2 ; 3.29^{\mathrm{d}} \pm 3.2(3.4)$ & $0.5^{\mathrm{c}} \pm 0.1 ; 0.5^{\mathrm{d}} \pm 3.4$ & $<0.001$ \\
\hline
\end{tabular}

${ }^{\text {a }}$ Seven normal parathyroid glands obtained from patients undergoing euthyroid surgery and three from patients undergoing single parathyroid adenoma removal.

${ }^{\mathrm{b}}$ From the three PHPT patients only.

${ }^{\mathrm{c}}$ Arithmetic mean.

${ }^{\mathrm{d}}$ Geometric mean. 

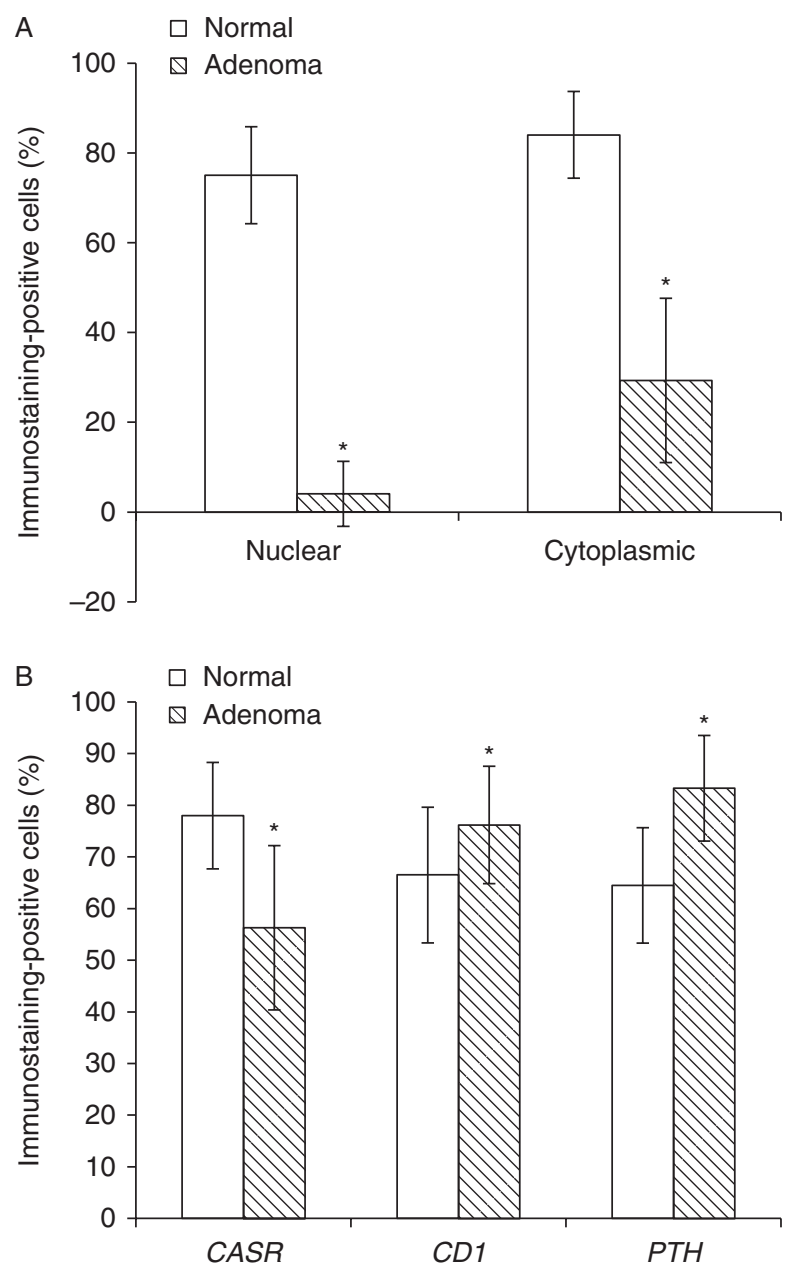

Figure 1 Bar diagrams representing immunostaining-positive cells indicating (A) VDR expression in nucleus and cytoplasm (B) CASR, $C D 1$, and $P T H$ expression in parathyroid normal and adenoma tissues respectively. All values are expressed as mean \pm s.D., ${ }^{\star} P<0.05$.

adenomas. All the normal parathyroid tissue cells showed $3+$ membranous positivity (Fig. 4).

The CASR mRNA expression was reduced in $90 \%$ of the adenoma cells with a mean fold change of 0.45 \pm 0.35 compared with normal parathyroid tissue cells $(P<0.001$; Fig. 3A). There was no significant relationship of CASR mRNA expression to disease indices (corrected calcium, intact PTH, 25-hydroxyvitamin D, or adenoma weight).

\section{CD1 expression}

All the parathyroid adenomas showed cytoplasmic positivity, while normal parathyroid tissues showed intense nuclear as well as cytoplasmic positivity. The mean proportion of positive cells was $76.2 \pm 11.4 \%$ compared with $66.5 \pm 13.1 \%$ in normal parathyroid tissues $(P<0.05$; Fig. 1B). Stain intensity was $1+$ in $18(44 \%), 2+$ in $14(34 \%)$, and $3+$ in $9(22 \%)$ adenomas (Fig. 5). Normal parathyroid tissue samples showed $2+$ to $3+$ staining positivity for CD1.

The CD1 mRNA expression was increased in $85.4 \%$ of the adenomatous compared with normal parathyroid tissue cells with a mean fold change of $9.45 \pm 8.86$ $(P<0.001$; Fig. 3B). The frequency of CD1 overexpression was related to the adenoma weight $(r=0.715$; $P<0.001$; Fig. 6) but not with albuminadjusted calcium, intact PTH, or 25-hydroxyvitamin D.

\section{PTH expression}

All the parathyroid adenoma cells showed diffuse cytoplasmic positivity in $83.3 \pm 10.2 \%$ cells compared with $64.5 \pm 11.2 \%$ of normal parathyroid tissues $(P<0.05)$. Stain intensity was $1+$ in $15(37 \%), 2+$ in $17(41 \%)$, and $3+$ in $9(22 \%)$ adenomas. Staining intensity of PTH in normal parathyroid tissue samples was $2+$ to $3+$.

An increased expression of PTH mRNA was seen in all the parathyroid adenoma cells with variable fold change. The mean PTH mRNA fold change was $17.36 \pm 14.6$ (range 1.7-45.2 folds) in adenomatous compared with normal parathyroid tissue cells $(P<0.001$; Fig. 1B). In addition, the PTH analyses in the tissues served as 'internal controls', thus validating our other observations in this study. The PTH mRNA overexpression was related to intact PTH $(r=0.864$; $P<0.001)$ but not with albumin-adjusted calcium, 25-hydroxyvitamin D, or adenoma weight.

\section{Discussion}

This is the comprehensive study of relevant candidate gene expressions in parathyroid adenomas with symptomatic PHPT, as commonly seen in India.
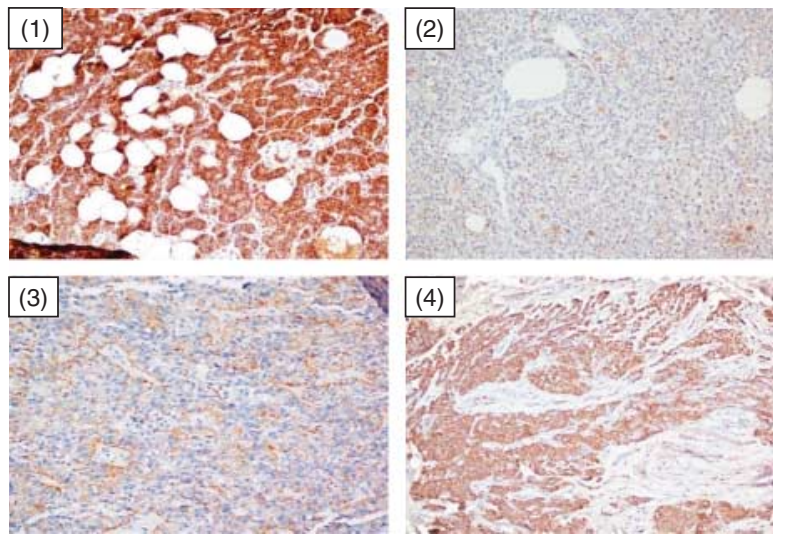

Figure 2 Microphotographs showing localization of VDR expression in tissue sections of parathyroid gland. (1) Normal and (2, 3 and 4) represent intensity score in adenoma as $1+, 2+$, and $3+$ respectively. (2) Is in $10 \times$ and other figures are in $20 \times$ magnification. Full colour version of this figure available via http://dx.doi.org/10.1530/EJE-13-0085. 

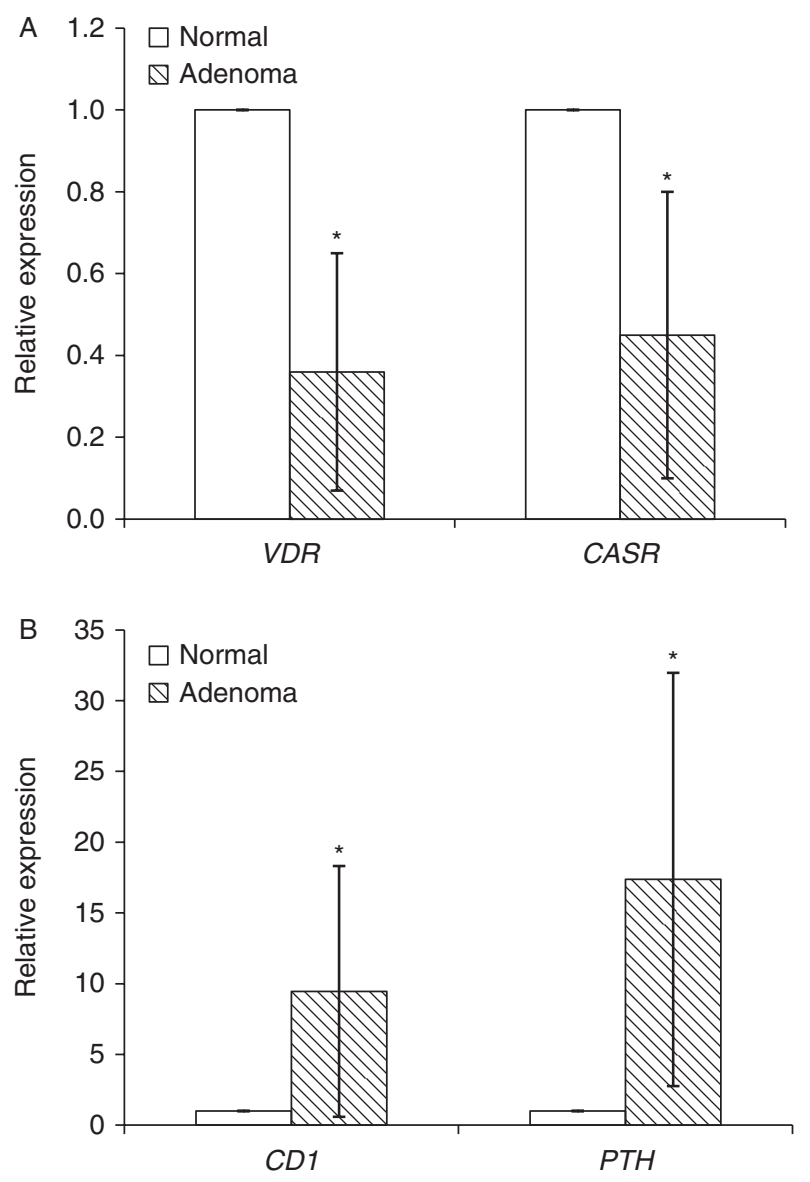

Figure 3 Bar diagrams showing qRT-PCR analysis of (A) VDR and $C A S R$ expression and (B) $C D 1$ and $P T H$ expression in normal parathyroid glands and adenomas. ${ }^{*} P<0.001$.

We found significantly reduced VDR and CASR and increased CD1 and PTH expressions in parathyroid adenomas compared with normal parathyroid tissue. In addition, we demonstrated a positive relationship between CD1 overexpression and adenoma weight. The major clinical manifestation in our patient group was bone pain and more than half of our patients had bone involvement. Our previous study (24) and a recent publication from China (28) have also shown that PHPT is still symptomatic with bone manifestations in this part of the world.

The downregulation of VDR expression in parathyroid adenomas in patients with symptomatic PHPT is similar to previous report of probably mild PHPT patients (12). Because the normal parathyroid tissues in our samples showed both nuclear and cytoplasmic positivity, we separately assessed nuclear and cytoplasmic VDR expression and found decreased expression of VDR at both cellular locations in parathyroid adenomas. This is the first time such a separate analysis has been performed as there is no mention of cytoplasmic VDR assessment in previous studies $(13,14)$ presumably considered as non-specific staining (12). Nuclear localization of VDR with subsequent binding to vitamin $\mathrm{D}$ response elements (VDREs) in target genes is essential for vitamin D biological activity. The balance between the cellular compartments (nuclear/cytoplasmic) is probably relevant to the regulatory actions of vitamin D. More pronounced cytoplasmic VDR staining could indicate an 'escape' of parathyroid adenoma cells from homeostatic surveillance and growth control, especially if the regulatory mechanisms depended on ligand-activated receptor activity (29). Such alterations in cytoplasmic and nuclear VDR staining have also been reported in other neoplasms $(30,31,32)$.

Reduced CASR expression was also found in adenomas compared with normal parathyroid tissue cells, and the magnitude of reduction was similar to previous reports on patients probably having mild forms of PHPT $(12,14,15,16,17,18)$. Decreased CASR expression in parathyroid adenomas would be consistent with a less efficient control of PTH synthesis and secretion by calcium. The CASR gene has VDREs in the $5^{\prime}$-flanking region and is regulated by binding 1,25-dihydroxyvitamin D and VDR complex to VDREs (33, 34); thus, the reduction in CASR could be a consequence of reduced VDR. Previously, it has been suggested that reduced CASR expression could be the initiating event in parathyroid tumorigenesis (35). However, it seems more likely that CASR reduction is secondary to reduction in VDR expression as we found a greater magnitude of reduction in VDR compared with CASR expression. This could be explained by inhibition of gene transcription, less stable mRNA or posttranslational modification, or gene silencing by hypermethylation in the promoter region as suggested by previous studies $(12,13,18)$. It seems unlikely that hypercalcemia or elevated serum PTH, or adenomatous
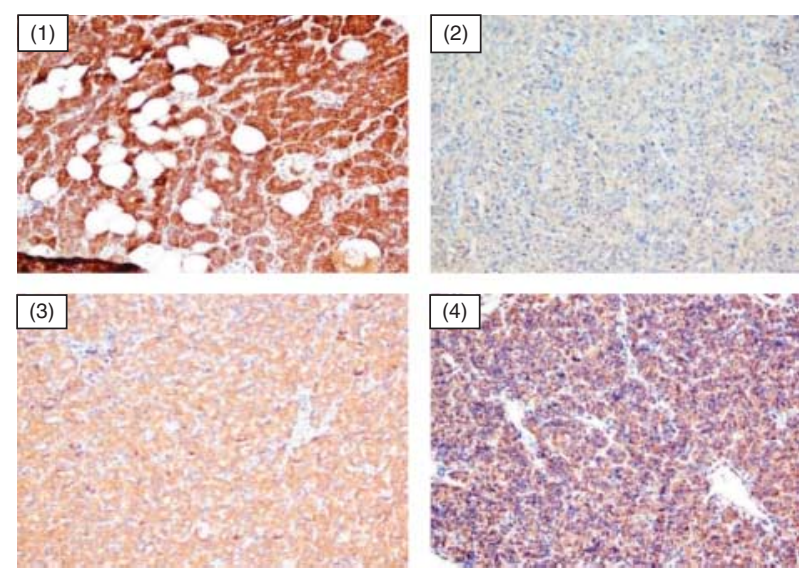

Figure 4 Microphotographs showing CASR expression in tissue sections of parathyroid gland. (1) Normal and (2, 3 and 4) represent intensity score in adenoma as $1+, 2+$, and $3+$ respectively. (2) Is in $10 \times$ and other figures are in $20 \times$ magnification. Full colour version of this figure available via http://dx.doi.org/10.1530/ EJE-13-0085. 
transformation itself due to increased proliferative activity, is responsible for VDR and CASR downregulation $(12,13,18)$ as we found no correlation between adenoma weight and preoperative serum calcium, PTH, or 25-hydroxyvitamin D levels in our patients.

Interestingly, CD1 immunostaining was seen exclusively in the cytoplasm in all the samples without nuclear staining. In contrast, previous studies have observed both nuclear, and to a lesser degree, cytoplasmic staining $(19,20,21,22,23)$. Overexpression of CD1 both in nuclear and in cytoplasmic compartments has been reported in many human malignancies. CD1 plays an important role in proliferation and differentiation, and a shift between nucleus and cytoplasm is necessary to regulate smooth passage across different phases of the cell cycle. Cytoplasmic staining for $\mathrm{CD} 1$ occurs during $\mathrm{G}_{1}$ to $\mathrm{S}$ transition of the cell cycle, while nuclear staining is visualized only in $\mathrm{G}_{1}$ phase (36). CD1 expression is lowest during $S$ phase (37), perhaps explaining why we observed low intensities of CD1 in most of the adenomas comparing to normal parathyroid tissue.

We found overexpression of CD1 mRNA in $85 \%$ of the parathyroid adenomas in comparison to $20-40 \%$ reported previously $(19,20,21,22,23)$. Of the four genes (VDR, CASR, CD1, and PTH) analyzed in this study, only CD1 expression was significantly associated with parathyroid adenoma weight. Also, the increase in CD1 expression was numerically related to PTH level but did not quite reach statistical significance. This rather robust overexpression of $\mathrm{CD} 1$ could conceivably be related to the larger tumors, higher PTH levels, and more severe clinical expression of the disease in this part of the world. As we did not systematically examine the 'upstream' gene expressions (as was reported in a previous study (22)) either in this or our previous study (12), the potential role of overexpression of $\mathrm{CD} 1$ in

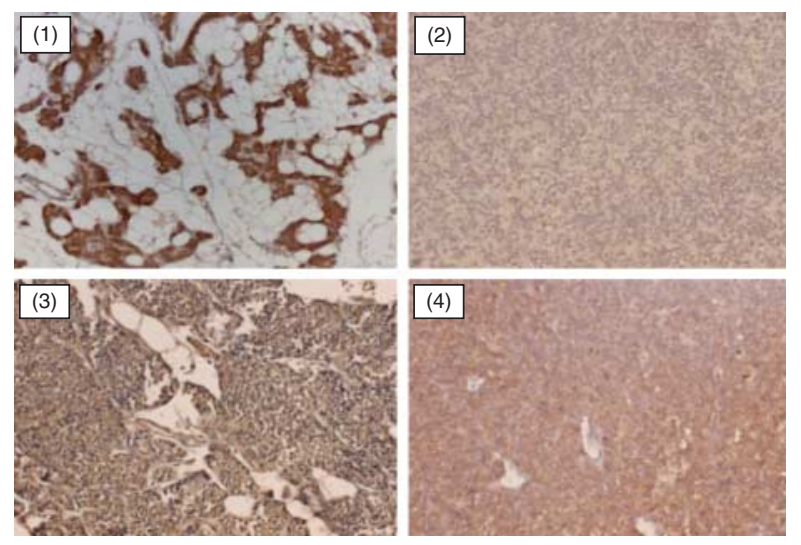

Figure 5 Microphotographs showing CD1 expression in tissue sections of parathyroid gland. (1) Normal and (2, 3 and 4) represent intensity score in adenoma as $1+, 2+$, and $3+$ respectively. (1) Is in $10 \times$ and other figures are in $20 \times$ magnification. Full colour version of this figure available via http://dx.doi.org/10.1530/ EJE-13-0085.

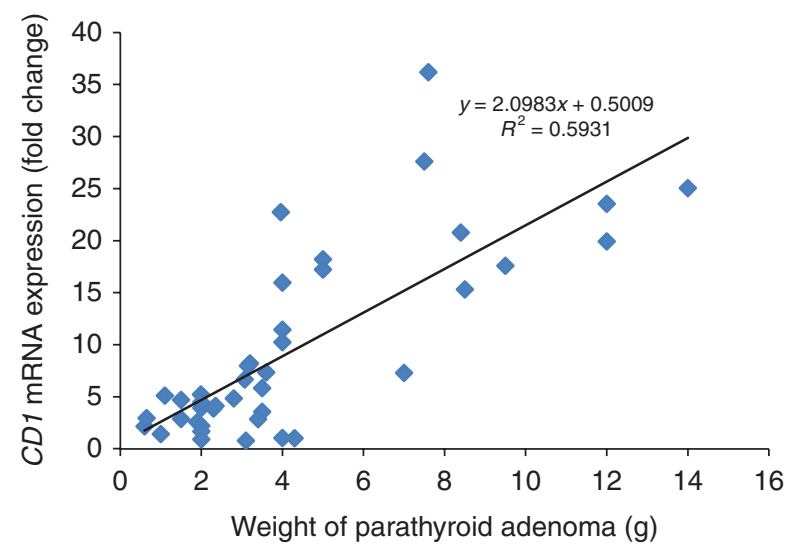

Figure 6 Correlation of $C D 1 \mathrm{mRNA}$ with weight of parathyroid adenomas. Full colour version of this figure available via http://dx. doi.org/10.1530/EJE-13-0085.

parathyroid adenoma size or differential expression of the disease requires further investigation.

There were certain limitations such as relatively small sample size, lack of comparable data from patients with mild PHPT, a phenotype rarely seen in India, smaller number of normal parathyroid tissue $(n=10)$, and our inability to measure serum 1,25-dihydroxyvitamin D levels for lack of resources. Nevertheless, the strength of our study is the simultaneous analysis of four relevant genes and demonstration of a similar magnitude of reductions in VDR and CASR in moderate severe PHPT just as in the cases reported to be probably having mild form of PHPT (12). Our study results also suggest that the mechanisms underlying parathyroid tumorigenesis and their growth behavior are probably different.

In conclusion, we have demonstrated reduced VDR and CASR expression and increased CD1 and PTH by immunohistochemistry and confirmed with the respective mRNA analyses in parathyroid adenomas. In addition, we found that overexpression of CD1 correlated with the weight of parathyroid adenoma. Further investigations of the pathway of these genes with larger sample size could help better understand the pathogenesis and progression of disease in patients with severe PHPT and unravel potential new therapeutic targets.

\section{Supplementary data}

This is linked to the online version of the paper at http://dx.doi.org/10. 1530/EJE-13-0085.

\section{Declaration of interest}

The authors declare that there is no conflict of interest that could be perceived as prejudicing the impartiality of the research reported.

\section{Funding}

This work was partially supported by a grant from the Indian Council of Medical Research (ICMR), New Delhi India (IRIS ID no. 2009-04680). 


\section{Acknowledgements}

The authors thank Dr Rajesh Khadgawat, Additional Professor, Department of Endocrinology, All India Institute of Medical Sciences (AIIMS), New Delhi, and Dr K Rajagopal from the Institute of Microbial Technology (IMTECH), Chandigarh, for their helpful discussions.

\section{References}

1 Marx SJ, Simonds WF, Agarwal SK, Burns AL, Weinstein LS, Cochran C, Skarulis MC, Spiegel AM, Libutti SK, Alexander HR Jr et al. Hyperparathyroidism in hereditary syndromes: special expressions and special managements. Journal of Bone and Mineral Research 200217 (Suppl 2) N37-N43.

2 Brown EM, Pollak M, Seidman CE, Seidman JG, Chou YH, Riccardi D \& Hebert SC. Calcium-ion-sensing cell-surface receptors. New England Journal of Medicine 1995333 234-240. (doi:10.1056/NEJM199508243330826)

3 Brown EM, Wilson RE, Thatcher JG \& Marynick SP. Abnormal calcium-regulated PTH release in normal parathyroid tissue from patients with adenoma. American Journal of Medicine 198171 565-570. (doi:10.1016/0002-9343(81)90207-2)

4 Dokoh S, Donaldson CA \& Haussler MR. Influence of 1,25-dihydroxyvitamin D3 on cultured osteogenic sarcoma cells: correlation with the 1,25-dihydroxyvitamin D3 receptor. Cancer Research 198444 2103-2109.

5 Garabedian M, Holick MF, Deluca HF \& Boyle IT. Control of 25-hydroxycholecalciferol metabolism by parathyroid glands. PNAS 197269 1673-1676. (doi:10.1073/pnas.69.7.1673)

6 Brenza HL, Kimmel-Jehan C, Jehan F, Shinki T, Wakino S, Anazawa H, Suda T \& DeLuca HF. Parathyroid hormone activation of the 25-hydroxyvitamin D3-1 $\alpha$-hydroxylase gene promoter. PNAS 199895 1387-1391. (doi:10.1073/pnas.95.4.1387)

7 DeLuca HF \& Zierold C. Mechanisms and functions of vitamin D. Nutrition Reviews $1998 \mathbf{5 6}$ S4-S10 (discussion S54-S75). (doi:10.1111/j.1753-4887.1998.tb01686.x)

8 Demay MB, Kiernan MS, DeLuca HF \& Kronenberg HM. Sequences in the human parathyroid hormone gene that bind the 1,25-dihydroxyvitamin D3 receptor and mediate transcriptional repression in response to 1,25-dihydroxyvitamin D3. PNAS 199289 8097-8101. (doi:10.1073/pnas.89.17.8097)

9 Arnold A, Kim HG, Gaz RD, Eddy RL, Fukushima Y, Byers MG, Shows TB \& Kronenberg HM. Molecular cloning and chromosomal mapping of DNA rearranged with the parathyroid hormone gene in a parathyroid adenoma. Journal of Clinical Investigation 198983 2034-2040. (doi:10.1172/JCI114114)

10 Palanisamy N, Imanishi Y, Rao PH, Tahara H, Chaganti RS \& Arnold A. Novel chromosomal abnormalities identified by comparative genomic hybridization in parathyroid adenomas. Journal of Clinical Endocrinology and Metabolism $1998 \mathbf{8 3}$ 1766-1770. (doi:10.1210/jc.83.5.1766)

11 Farnebo F, Kytola S, Teh BT, Dwight T, Wong FK, Hoog A, Elvius M, Wassif WS, Thompson NW, Farnebo LO et al. Alternative genetic pathways in parathyroid tumorigenesis. Journal of Clinical Endocrinology and Metabolism 199984 3775-3780. (doi:10.1210/jc.84.10.3775)

12 Sudhaker Rao D, Han ZH, Phillips ER, Palnitkar S \& Parfitt AM. Reduced vitamin D receptor expression in parathyroid adenomas: implications for pathogenesis. Clinical Endocrinology $2000 \mathbf{5 3}$ 373-381. (doi:10.1046/j.1365-2265.2000.01081.x)

13 Carling T, Rastad J, Szabo E, Westin G \& Akerstrom G. Reduced parathyroid vitamin D receptor messenger ribonucleic acid levels in primary and secondary hyperparathyroidism. Journal of Clinical Endocrinology and Metabolism 200085 2000-2003. (doi:10.1210/jc.85.5.2000)

14 Yano S, Sugimoto T, Tsukamoto T, Chihara K, Kobayashi A, Kitazawa S, Maeda S \& Kitazawa R. Decrease in vitamin D receptor and calcium-sensing receptor in highly proliferative parathyroid adenomas. European Journal of Endocrinology 2003 148 403-411. (doi:10.1530/eje.0.1480403)

15 Kifor O, Moore FD Jr, Wang P, Goldstein M, Vassilev P, Kifor I, Hebert SC \& Brown EM. Reduced immunostaining for the extracellular $\mathrm{Ca}^{2+}$-sensing receptor in primary and uremic secondary hyperparathyroidism. Journal of Clinical Endocrinology and Metabolism 199681 1598-1606. (doi:10.1210/jc.81.4.1598)

16 Farnebo F, Enberg U, Grimelius L, Backdahl M, Schalling M, Larsson C \& Farnebo LO. Tumor-specific decreased expression of calcium sensing receptor messenger ribonucleic acid in sporadic primary hyperparathyroidism. Journal of Clinical Endocrinology and Metabolism 199782 3481-3486. (doi:10.1210/jc.82.10.3481)

17 Gogusev J, Duchambon P, Hory B, Giovannini M, Goureau Y, Sarfati E \& Drueke TB. Depressed expression of calcium receptor in parathyroid gland tissue of patients with hyperparathyroidism. Kidney International 199751 328-336. (doi:10.1038/ki.1997.41)

18 Garner SC, Hinson TK, McCarty KS, Leight M, Leight GS Jr \& Quarles LD. Quantitative analysis of the calcium-sensing receptor messenger RNA in parathyroid adenomas. Surgery 1997122 1166-1175. (doi:10.1016/S0039-6060(97)90223-3)

19 Hsi ED, Zukerberg LR, Yang WI \& Arnold A. Cyclin D1/PRAD1 expression in parathyroid adenomas: an immunohistochemical study. Journal of Clinical Endocrinology and Metabolism $1996 \mathbf{8 1}$ 1736-1739. (doi:10.1210/jc.81.5.1736)

20 Vasef MA, Brynes RK, Sturm M, Bromley C \& Robinson RA. Expression of cyclin D1 in parathyroid carcinomas, adenomas, and hyperplasias: a paraffin immunohistochemical study. Modern Pathology $199912412-416$.

21 Tominaga Y, Tsuzuki T, Uchida K, Haba T, Otsuka S, Ichimori T, Yamada K, Numano M, Tanaka Y \& Takagi H. Expression of PRAD1/cyclin D1, retinoblastoma gene products, and Ki67 in parathyroid hyperplasia caused by chronic renal failure versus primary adenoma. Kidney International 199955 1375-1383. (doi:10.1046/j.1523-1755.1999.00396.x)

22 Forsberg L, Bjorck E, Hashemi J, Zedenius J. Hoog A, Farnebo LO, Reimers M \& Larsson C. Distinction in gene expression profiles demonstrated in parathyroid adenomas by high-density oligoarray technology. European Journal of Endocrinology 2005 152 459-470. (doi:10.1530/eje.1.01864)

23 Żebracka-Gala J, Waler J, Gawrychowski J, Hasse-Lazar K, Kowalska M, Niemiec A, Szpak-Ulczok S, Jurecka-Lubieniecka B, Buła G, Truchanowski W et al. Jun gene expression is decreased in parathyroid adenoma. Polski Przeglad Chirurgiczny 200981 457-464.

24 Bhansali A, Masoodi SR, Reddy KS, Behera A, das Radotra B, Mittal BR, Katariya RN \& Dash RJ. Primary hyperparathyroidism in north India: a description of 52 cases. Annals of Saudi Medicine $20052529-35$.

25 Bhadada SK, Bhansali A, Dutta P, Behera A, Chanukya GV \& Mittal BR. Characteristics of primary hyperparathyroidism in adolescents. Journal of Pediatric Endocrinology E Metabolism 2008 21 1147-1153.

26 Bhadada SK, Bhansali A, Ahluwalia J, Chanukya GV, Behera A \& Dutta P. Anaemia and marrow fibrosis in patients with primary hyperparathyroidism before and after curative parathyroidectomy. Clinical Endocrinology 200970 527-532. (doi:10.1111/j.13652265.2008.03346.x)

27 Livak KJ \& Schmittgen TD. Analysis of relative gene expression data using real-time quantitative PCR and the 2(-Delta Delta C(T)) method. Methods 200125 402-408. (doi:10.1006/meth. 2001.1262)

28 Zhao L, Liu JM, He XY, Zhao HY, Sun LH, Tao B, Zhang MJ, Chen X, Wang WQ \& Ning G. The changing clinical patterns of primary hyperparathyroidism in Chinese patients: data from 2000 to 2010 in a single clinical center. Journal of Clinical Endocrinology and Metabolism 201398 721-728. (doi:10.1210/ jc.2012-2914)

29 Brozyna AA, Jozwicki W, Janjetovic Z \& Slominski AT. Expression of vitamin D receptor decreases during progression of pigmented skin lesions. Human Pathology 201142 618-631. (doi:10.1016/j. humpath.2010.09.014) 
30 Matusiak D, Murillo G, Carroll RE, Mehta RG \& Benya RV. Expression of vitamin D receptor and 25-hydroxyvitamin D3$1\{\alpha\}$-hydroxylase in normal and malignant human colon. Cancer Epidemiology, Biomarkers \& Prevention 200514 2370-2376. (doi:10.1158/1055-9965.EPI-05-0257)

31 Menezes RJ, Cheney RT, Husain A, Tretiakova M, Loewen G, Johnson CS, Jayaprakash V, Moysich KB, Salgia R \& Reid ME. Vitamin D receptor expression in normal, premalignant, and malignant human lung tissue. Cancer Epidemiology, Biomarkers \& Prevention 200817 1104-1110. (doi:10.1158/1055-9965.EPI-07-2713)

32 Tokumoto M, Tsuruya K, Fukuda K, Kanai H, Kuroki S \& Hirakata H. Reduced p21, p27 and vitamin D receptor in the nodular hyperplasia in patients with advanced secondary hyperparathyroidism. Kidney International 200262 1196-1207. (doi:10.1111/j.1523-1755.2002.kid585.x)

33 Guzey M, Kitada S \& Reed JC. Apoptosis induction by 1 $\alpha, 25$-dihydroxyvitamin D3 in prostate cancer. Molecular Cancer Therapeutics $20021667-677$.

34 Canaff L \& Hendy GN. Human calcium-sensing receptor gene. Vitamin D response elements in promoters $\mathrm{P} 1$ and $\mathrm{P} 2$ confer transcriptional responsiveness to 1,25-dihydroxyvitamin D. Journal of Biological Chemistry $2002 \quad 277$ 30337-30350. (doi:10.1074/jbc.M201804200)

35 Brown AJ, Zhong M, Finch J, Ritter C, McCracken R, Morrissey J \& Slatopolsky E. Rat calcium-sensing receptor is regulated by vitamin D but not by calcium. American Journal of Physiology 1996270 F454-F460.

36 Alt JR, Cleveland JL, Hannink M \& Diehl JA. Phosphorylationdependent regulation of cyclin D1 nuclear export and cyclin D1dependent cellular transformation. Genes and Development 2000 14 3102-3114. (doi:10.1101/gad.854900)

37 Hitomi M \& Stacey DW. Cellular ras and cyclin D1 are required during different cell cycle periods in cycling NIH $3 \mathrm{~T} 3$ cells. Molecular and Cellular Biology 199919 4623-4632.

Received 28 January 2013

Revised version received 19 April 2013

Accepted 9 May 2013 